\title{
Synthesis, crystal structures and properties of carbazole- based [6]helicenes fused with an azine ring
}

\author{
Daria I. Tonkoglazova1 ${ }^{1}$, Anna V. Gulevskaya ${ }^{* 1}$, Konstantin A. Chistyakov \\ and Olga I. Askalepova ${ }^{1}$
}

\author{
Full Research Paper \\ Address: \\ ${ }^{1}$ Department of Chemistry, Southern Federal University, Zorge str., 7, \\ Rostov-on-Don 344090, Russian Federation and ${ }^{2}$ I. Ya. Postovsky \\ Institute of Organic Synthesis, Ural Branch of the Russian Academy of \\ Sciences, S. Kovalevskaya Str., 22, Yekaterinburg 620219, Russian \\ Federation \\ Email: \\ Anna V. Gulevskaya* - agulevskaya@sfedu.ru \\ * Corresponding author \\ Keywords: \\ azine-fused helicenes; carbazole-based [6]helicenes; helical \\ structures
}

Beilstein J. Org. Chem. 2021, 17, 11-21.

https://doi.org/10.3762/bjoc.17.2

Received: 21 October 2020

Accepted: 07 December 2020

Published: 04 January 2021

Associate Editor: P. J. Skabara

(C) 2021 Tonkoglazova et al.; licensee Beilstein-Institut. License and terms: see end of document.

\begin{abstract}
Novel carbazole-based [6]helicenes fused with an azine ring (pyridine, pyrazine or quinoxaline) have been prepared through a fivestep synthetic sequence in good overall yields. Commercially available 2,3-dihaloazines were used as starting materials. To discern the effect of merging an azine moiety within a helical skeleton, the X-ray structures, UV-vis absorption and fluorescence spectra of the helicenes were investigated and compared to that of the parent carbazole-based [6]helicene (7H-phenanthro[3,4-c]carbazole).
\end{abstract}

\section{Introduction}

$[n]$ Helicenes are polycyclic aromatic molecules with nonplanar screw-shaped helical skeletons formed by $n$-ortho-fused benzene or other aromatic rings. Their helical structure is a consequence of the steric repulsion of the terminal aromatic nuclei. The steric strain releases by adopting either the $P$ - or $M$-helix configuration. The helically extended $\pi$-conjugated system, axial chirality and associated with these structural peculiarities unique optical and electronic properties of helicenes have attracted scientific interest for decades [1-11]. Compared to other planar $\pi$-conjugated systems, helicenes are more thermally stable and soluble in common organic solvents [9]. This fact together with the exceptionally high values of specific optical rotation and strong circular dichroism have led to promising applications of helicenes. The latter have been studied with respect to conductivity [12-15], nonlinear optics [16,17], circularly polarized luminescence [18-24], organocatalysis [2529], conformational analysis [30], chirality sensing [31], chemical sensors [32], DNA-intercalators [33,34] etc.

Besides typical carbohelicenes, heterohelicenes, incorporating one or more heteroaromatic units in the skeleton, have also gained increasing attention [1-11]. The presence of heteroatoms 
$(\mathrm{S}, \mathrm{N}, \mathrm{O}, \mathrm{P})$ in the fused polycyclic $\pi$-systems additionally contributes to altering electronic structure and helps to fine tune optoelectronic properties [1-11,20,35-37]. The last decades highlighted heterohelicenes, incorporating one or two carbazole fragments, as a very attractive class of molecules [38-51]. This is not surprising, taking into account the excellent thermal stability, the strong electron-donating nature, a good hole-transporting ability of the carbazole unit and, as a consequence, numerous applications of the carbazole-based electroactive materials [52-54]. Carbazole-based [6]helicenes [42] and [7]helicenes [50] showed deep blue electroluminescence and have been investigated in OLED devices. Some carbazole-based [5]- and [6]helicenes have been used as visible light photoinitiators for cationic and radical polymerization [41]. [7]Helicenes of this group demonstrated a relatively high electron affinity and could be good candidates for electron-injection hole-blocking layers [39]. Donor-acceptor hybride [6]helicenes, consisting of carbazole and phenanthridine cores, are interesting as holetransporting compounds [47]. At last, carbazole-based heterohelicenes were found in nature, for example, purpurone [55] isolated from the marine sponge Iotrochota $s p$. and having an inhibitory effect on the ATP-citrate lyase, and the marine alkaloid ningalin D produced by Didemnum sp., Dictyodendrins [56] isolated from Dictyodendrilla $s p$. and displaying inhibitory activities towards telomerases.

The classical synthetic approach for carbohelicenes is the oxidative photocyclization of stilbene derivatives [1-11]. The latter are generally available via the Wittig, Heck-type or McMurry couplings. It is also a useful way to synthesize heterohelicenes, in particular, carbazole-based helicenes [39-42,44,47,48,50,51] (Scheme 1A). However, photocyclization of the stilbene substrates, having two non-equivalent ortho positions, leads to the formation of isomeric polynuclear molecules, which are often difficult to separate. Another drawback of this method is the difficulty of scaling, since the reaction requires strong dilution to prevent the $[2 \pi+2 \pi]$ dimerization of the starting stilbene. Among other approaches to the carbazole-based helicenes are the Diels-Alder reaction of silyl enol ethers of 3,6-diacetylcarbazole with $p$-benzoquinone (Scheme 1B) [49], the double Buchwald-Hartwig amination of 4,4'-biphenanthrene derivatives (Scheme 1C) [45] and a enantioselective Fischer indolization-oxidation protocol (Scheme 1D) [43]. Each method is not without drawbacks such as hardly available starting materials, rather expensive catalysts, harsh reaction conditions or low product yields.

Transition-metal-catalyzed, electrophile-induced and oxidative radical cyclizations of ortho-alkynylated biaryls are widely used for the synthesis of polynuclear aromatics [57-69]. Recently, we have described a versatile method for the preparation of

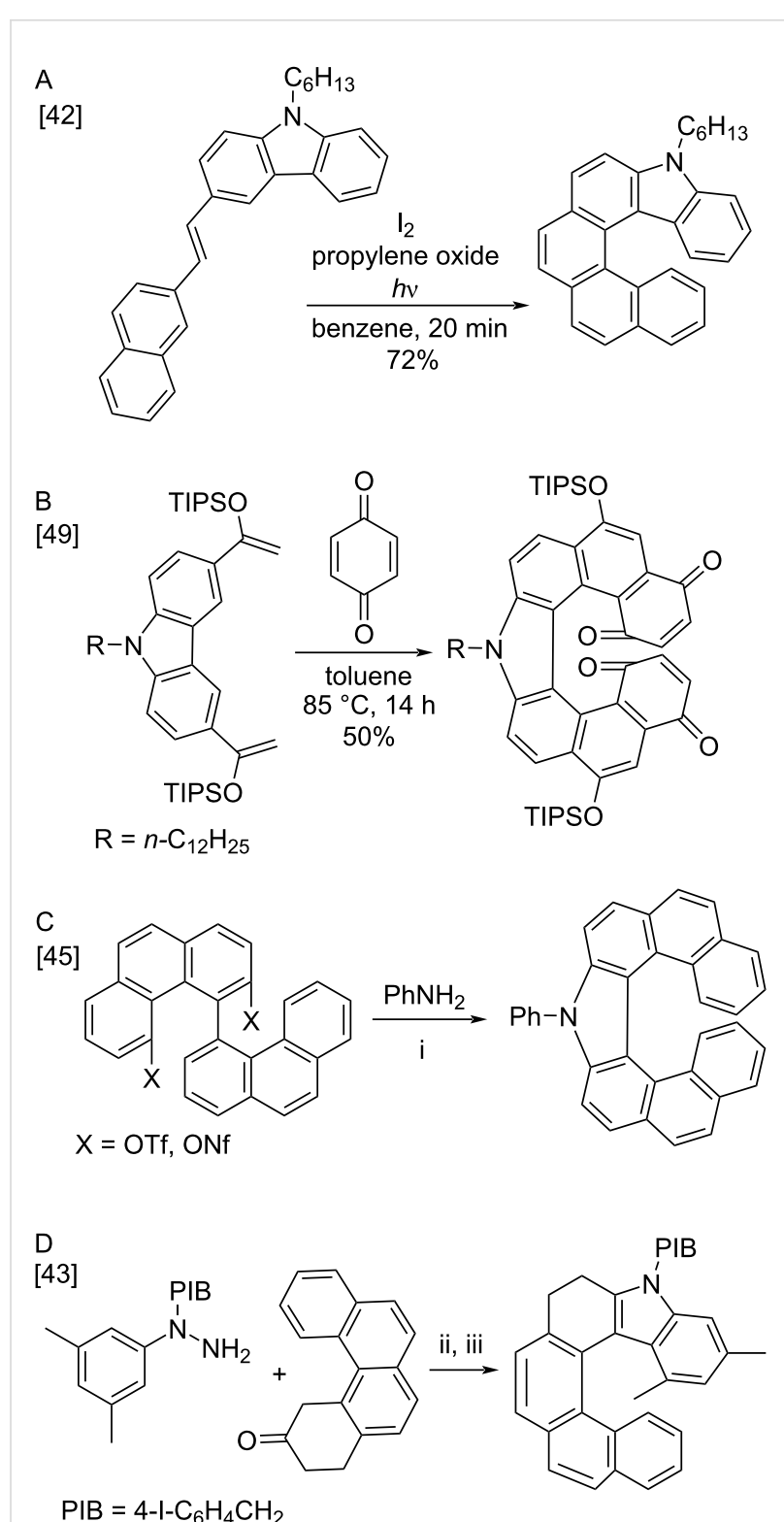

Scheme 1: Overview of the synthetic methods for the carbazole-based heterohelicenes. i) $\mathrm{Pd}_{2} \mathrm{dba}_{3}$, xantphos, $\mathrm{K}_{3} \mathrm{PO}_{4}$, xylene, $100{ }^{\circ} \mathrm{C}, 123 \mathrm{~h}$, $64-88 \%$ ii) SPINOL-derived phosphoric acid, Amberlite CG50, $\mathrm{CH}_{2} \mathrm{Cl}_{2}$, $-7{ }^{\circ} \mathrm{C}, 72 \mathrm{~h}, 74 \%$; iii) chloranil, diphenyl phosphate, $\mathrm{CHCl}_{3}, 50{ }^{\circ} \mathrm{C}$, $5 \mathrm{~h}, 76 \%$.

aza[4]helicenes [70], diaza[4]helicenes [70,71] and azine-fused [5]helicenes [72] through a five-step synthetic sequence, using commercially available 2,3-dihaloazines as starting materials. Based on this approach, we synthesized carbazole-based [6]helicenes fused with an azine ring (quinoxaline, pyrazine or pyridine ones). Scheme 2 represents the current work. We envisaged that combining the carbazole unit with the readily available azine building block would result in the formation of donor-acceptor hybrid helicenes with interesting electronic properties. 


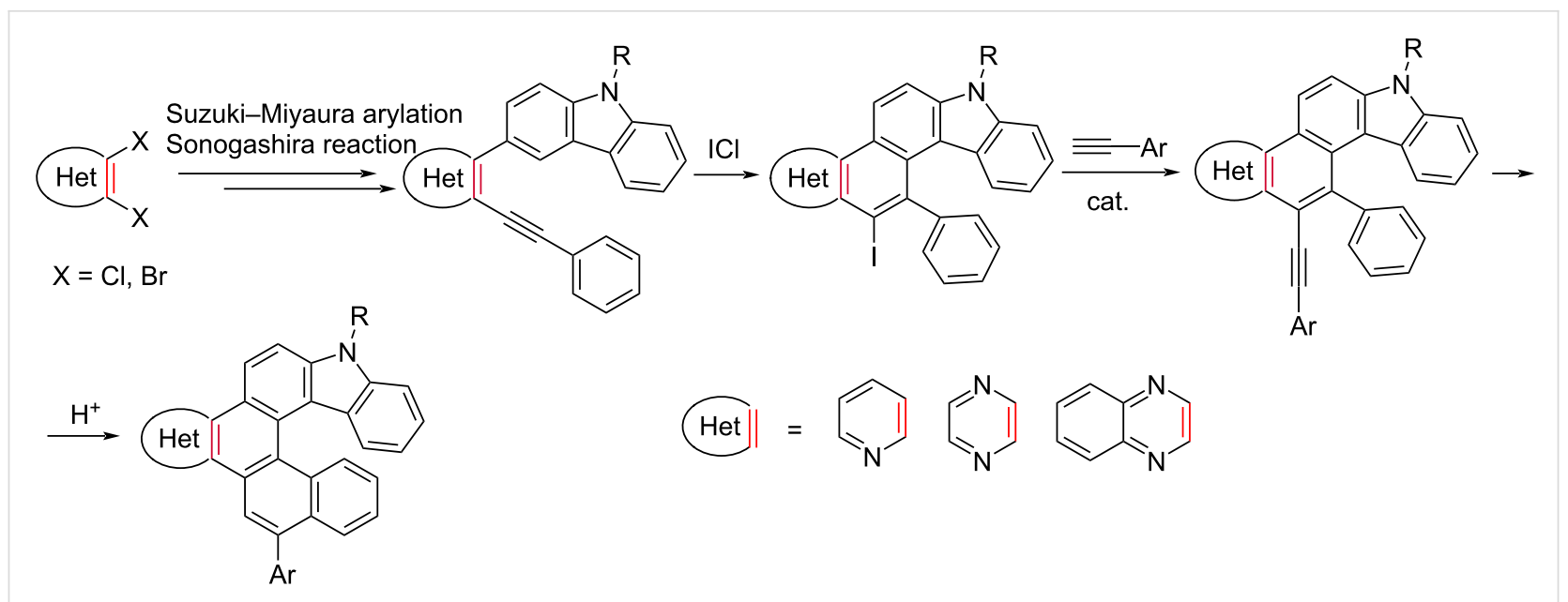

Scheme 2: Synthetic strategy for the carbazole-based [6]helicenes fused with an azine ring.

\section{Results and Discussion Synthesis}

In accordance with the above strategy, we first synthesized ortho-halogen alkynylazines $\mathbf{1 a , b}$ via the Sonogashira reaction of commercially available 2,3-dichloroquinoxaline and 2,3dichloropyrazine with phenylacetylene using a known procedure [70]. Coupling of compounds 1a,b with 9-ethyl-3-(4,4,5,5tetramethyl-1,3,2-dioxaborolan-2-yl)- $9 \mathrm{H}$-carbazole in the $\mathrm{Pd}\left(\mathrm{PPh}_{3}\right)_{4} / \mathrm{K}_{2} \mathrm{CO}_{3} / 1$,4-dioxane $/ \mathrm{H}_{2} \mathrm{O}$ catalytic system for $24 \mathrm{~h}$ at $100{ }^{\circ} \mathrm{C}$ (method $\mathrm{C}$ ) afforded the desired 3-alkynyl-2-carbazolylazines 2a,b in $82-96 \%$ yields (Table 1). Other catalytic systems $\mathrm{Pd}\left(\mathrm{PPh}_{3}\right)_{4} / \mathrm{K}_{3} \mathrm{PO}_{4} / \mathrm{THF}(\operatorname{method} \mathrm{A})$ and $\mathrm{Pd}\left(\mathrm{PPh}_{3}\right)_{4} / \mathrm{K}_{3} \mathrm{PO}_{4} / 1,4-$ dioxane (method $\mathrm{B}$ ) were less effective.

3-Alkynyl-2-carbazolylazines can also be prepared using an alternative synthetic sequence, i.e., the Suzuki-Miyaura arylation-Sonogashira reaction. It should be noted that in the case of 2,3-dibromopyridine it was the only way for us to synthesize the target [4]helicenes [70]. Unfortunately, the coupling of 2,3dichloroquinoxaline (3a) with 9-ethyl-3-(4,4,5,5-tetramethyl1,3,2-dioxaborolan-2-yl)- $9 H$-carbazole in the $5 \% \mathrm{Pd}-\mathrm{C} / \mathrm{PPh}_{3} /$ $\mathrm{K}_{2} \mathrm{CO}_{3} /$ toluene $/ \mathrm{H}_{2} \mathrm{O}$ catalytic system at $100{ }^{\circ} \mathrm{C}$ for $24 \mathrm{~h}$ (method A) gave the corresponding carbazolyl derivative 4a in $15 \%$ yield only (Table 2 ). The $\mathrm{Pd}\left(\mathrm{PPh}_{3}\right)_{4} / \mathrm{K}_{2} \mathrm{CO}_{3} / 1$,4-dioxane/ $\mathrm{H}_{2} \mathrm{O}$ catalytic system (method B) was more effective producing 4a in $63 \%$ yield. Thus, it was not the way for the synthesis of compounds 2a,b. Arylation of 2,3-dibromopyridine using the $\mathrm{Pd}\left(\mathrm{PPh}_{3}\right)_{4} / \mathrm{K}_{2} \mathrm{CO}_{3} / 1,4$-dioxane $/ \mathrm{H}_{2} \mathrm{O}$ catalytic system gave a mixture of the corresponding mono- and dicarbazolyl derivatives $\mathbf{4 b}(80 \%)$ and $\mathbf{5 b}(8 \%)$. The products were easily separated by column chromatography. 3-Bromo-2-carbazolylpyridine 4b was then introduced into the Sonogashira reaction with phenylacetylene giving rise to 3-alkynyl-2-carbazolylpyridine 6 in $74 \%$ yield (Scheme 3 ).

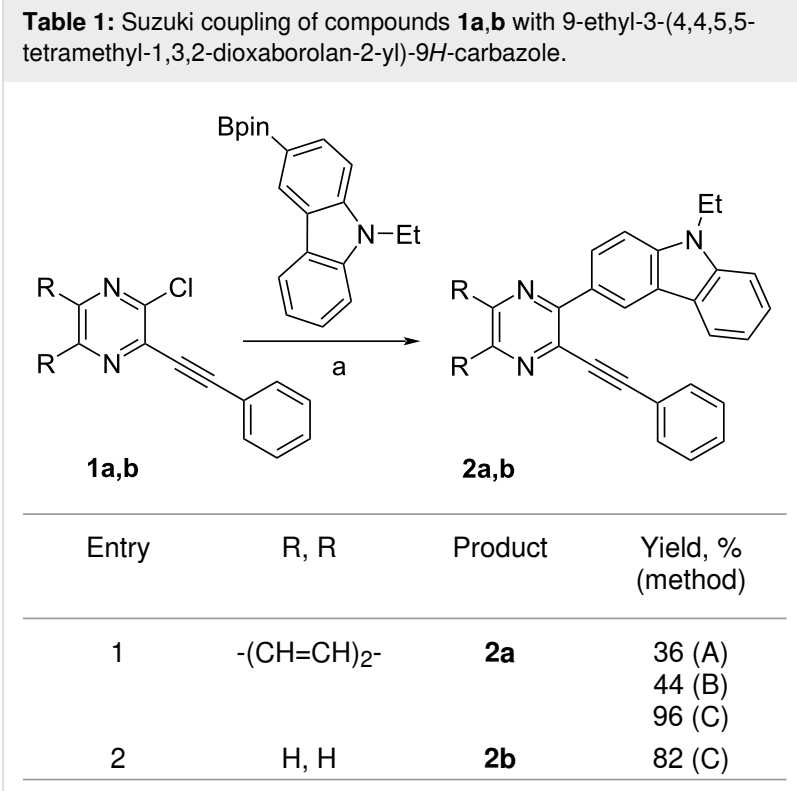

aMethod $\mathrm{A}$ : $\mathrm{Pd}\left(\mathrm{PPh}_{3}\right)_{4}, \mathrm{~K}_{3} \mathrm{PO}_{4}$, THF, reflux, $24 \mathrm{~h}$, argon; method $\mathrm{B}$ : $\mathrm{Pd}\left(\mathrm{PPh}_{3}\right)_{4}, \mathrm{~K}_{3} \mathrm{PO}_{4}, 1,4$-dioxane, $100{ }^{\circ} \mathrm{C}, 24 \mathrm{~h}$, argon; method $\mathrm{C}$ : $\mathrm{Pd}\left(\mathrm{PPh}_{3}\right)_{4}, \mathrm{~K}_{2} \mathrm{CO}_{3}, 1,4$-dioxane, $\mathrm{H}_{2} \mathrm{O}, 100{ }^{\circ} \mathrm{C}, 24 \mathrm{~h}$, argon.

Electrophilic cyclizations of 3-alkynyl-2-carbazolylazines 2a,b and $\mathbf{6}$ into azine-fused carbazoles $7 \mathbf{a}-\mathbf{c}$ were carried out with $\mathrm{ICl}$ in dry acetonitrile at room temperature in the dark (Table 3). In the cases of compounds $\mathbf{2 a}, \mathbf{b}$, the reaction was found to be very sensitive to the amount of ICl used. In the case of $\mathbf{2 a}$, the use of a 1.5-fold excess of ICl led to a hardly separable mixture of compound 7a and diiodo derivative 8a (Table 3, entry 1, for the NMR spectrum of the mixture see Supporting Information File 1, Figure S13). Iodine chloride, taken in an equimolar amount, made it possible to obtain the required product $7 \mathbf{a}$ in $65 \%$ yield and to remove minor impurities of diiodo derivative 8a by chromatography (Table 3 , entry 2 ). For the selective syn- 
Table 2: Suzuki coupling of compounds 3 with 9-ethyl-3-(4,4,5,5-tetramethyl-1,3,2-dioxaborolan-2-yl)-9H-carbazole.

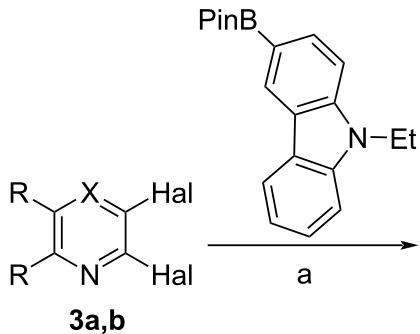<smiles>[R][Y]1c([R])c([R])nc(-c2ccc3c(c2)c2ccccc2n3CC)c1[131I]</smiles><smiles></smiles>

\begin{tabular}{|c|c|c|c|c|c|}
\hline Entry & $x$ & $\mathrm{R}, \mathrm{R}$ & Hal & Product & $\begin{array}{c}\text { Yield, \% } \\
\text { (method) }\end{array}$ \\
\hline 1 & $\mathrm{~N}$ & $-(\mathrm{CH}=\mathrm{CH})_{2^{-}}$ & $\mathrm{Cl}$ & $4 a$ & $\begin{array}{l}15(\mathrm{~A}) \\
63(\mathrm{~B})\end{array}$ \\
\hline 2 & $\mathrm{CH}$ & $\mathrm{H}, \mathrm{H}$ & $\mathrm{Br}$ & $\begin{array}{l}4 b \\
5 b\end{array}$ & $\begin{array}{l}80 \text { (B) } \\
8(\mathrm{~B})\end{array}$ \\
\hline
\end{tabular}

aMethod A: 5\% Pd/C, $\mathrm{PPh}_{3}, \mathrm{~K}_{2} \mathrm{CO}_{3}, \mathrm{H}_{2} \mathrm{O}$, toluene, $100{ }^{\circ} \mathrm{C}, 24 \mathrm{~h}$, argon; method $\mathrm{B}: \mathrm{Pd}\left(\mathrm{PPh}_{3}\right)_{4}, \mathrm{~K}_{2} \mathrm{CO}_{3}, 1,4-$ dioxane, $\mathrm{H}_{2} \mathrm{O}, 100{ }^{\circ} \mathrm{C}, 24 \mathrm{~h}$, argon.<smiles>CCn1c2ccccc2c2cc(-c3ncccc3C#Cc3ccccc3)ccc21</smiles>

Scheme 3: Sonogashira coupling of compound $\mathbf{4 b}$ with phenylacetylene. i) $\mathrm{Pd}\left(\mathrm{PPh}_{3}\right)_{2} \mathrm{Cl}_{2}, \mathrm{Cul}, \mathrm{Pr}_{2} \mathrm{NH}, \mathrm{DMSO}, 80^{\circ} \mathrm{C}, 24 \mathrm{~h}$, argon. thesis of $\mathbf{7 b}$, iodine chloride was taken in a small deficit (Table 3, entries 3 and 4). Compound $\mathbf{8 b}$ was synthesized in $97 \%$ yield by the treatment with a 3 -fold excess of $\mathrm{ICl}$ on monoiodide $\mathbf{7 b}$. The ICl-induced cyclization of the pyridinebased starting compound $\mathbf{6}$ proceeded smoothly giving rise to product $7 \mathrm{c}$ in $62 \%$ (Table 3 , entry 5 ). It should be noted that compounds $\mathbf{7 a}, \mathbf{7 b}$ and $\mathbf{7 c}$ are derivatives of the previously unknown heterocyclic systems $1 H$-carbazolo[3,4- $a$ ]phenazine, $7 H$-quinoxalino[5,6-c]carbazole and $7 H$-quinolino[8,7c]carbazole, respectively (SciFinder data).

Table 3: ICl-induced cyclyzation of compounds 2 and 6 .<smiles>[R]c1[X]c(C#Cc2ccccc2)c(-c2ccc3c(c2)c2ccccc2n3CC)nc1[R]</smiles>

2a,b, 6

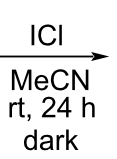
dark<smiles>CCn1c2ccccc2c2c3c(-c4ccccc4)c(I)ccc3ccc21</smiles>

$7 a-c$<smiles></smiles>

$8 a-c$

\begin{tabular}{|c|c|c|c|c|c|}
\hline Entry & $x$ & $\mathrm{R}, \mathrm{R}$ & $\mathrm{ICI}$, equiv & Product & Yield, \% \\
\hline 1 & $\mathrm{~N}$ & $-(\mathrm{CH}=\mathrm{CH})_{2^{-}}$ & 1.5 & $7 a+8 a$ & $\begin{array}{l}92 \text { (total) } \\
7.7: 1 \text { ratio }\end{array}$ \\
\hline 2 & $\mathrm{~N}$ & $-(\mathrm{CH}=\mathrm{CH})_{2^{-}}$ & 1 & $7 a$ & 65 \\
\hline 3 & $\mathrm{~N}$ & $\mathrm{H}, \mathrm{H}$ & 1 & $7 b+8 b$ & $\begin{array}{l}69 \text { (total) } \\
10: 1 \text { ratio }\end{array}$ \\
\hline 4 & $\mathrm{~N}$ & $\mathrm{H}, \mathrm{H}$ & 0.75 & $7 b$ & 75 \\
\hline 5 & $\mathrm{CH}$ & $\mathrm{H}, \mathrm{H}$ & 1 & $7 c$ & 62 \\
\hline
\end{tabular}


The fourth step of the synthesis of the target helicenes, namely the Sonogashira coupling of iodides $\mathbf{7 a}$ and $\mathbf{7} \mathbf{c}$ with $p$-tolylacetylene, was carried out in the $\mathrm{Pd}\left(\mathrm{PPh}_{3}\right)_{2} \mathrm{Cl}_{2} / \mathrm{CuI} / \mathrm{Et}_{3} \mathrm{~N} / \mathrm{THF}$ catalytic system that proved itself well in the azine-fused [5]helicenes synthesis [72] (Table 4, entries 1 and 3). The corresponding compounds 9a and 9c were obtained in 84 and $88 \%$ yields, respectively. In the case of $\mathbf{7 b}$, the reaction was more selective without THF solvent producing alkyne 9b in $82 \%$ yield (Table 4, entry 2). The structure of $\mathbf{9 c}$ was unambiguously proved by X-ray structural analysis (see Supporting Information File 1, Figure S34).

Table 4: Sonogashira coupling of compounds 7 with $p$-tolylacetylene.<smiles></smiles>

\begin{tabular}{cccccc}
\hline Entry & $\mathrm{X}$ & $\mathrm{R}, \mathrm{R}$ & Solvent & Product & Yield, \% \\
\hline 1 & $\mathrm{~N}$ & $-(\mathrm{CH}=\mathrm{CH})_{2^{-}}$ & THF & $9 \mathbf{a}$ & 84 \\
2 & $\mathrm{~N}$ & $\mathrm{H}, \mathrm{H}$ & - & $9 \mathrm{~b}$ & 82 \\
3 & $\mathrm{CH}$ & $\mathrm{H}, \mathrm{H}$ & THF & $9 \mathrm{c}$ & 88
\end{tabular}

$\operatorname{apd}\left(\mathrm{PPh}_{3}\right)_{2} \mathrm{Cl}_{2}, \mathrm{Cul}, \mathrm{Et}_{3} \mathrm{~N}$, solvent, $85^{\circ} \mathrm{C}, 24 \mathrm{~h}$, argon.

Earlier, at the final step of a similar synthesis of the azine-fused [5]helicenes, we used trifluoroacetic acid as a cyclizing agent
[72]. Unfortunately, only in the case of compound 9c, heating in trifluoroacetic acid led to isomerization into the required carbazole-based [6] helicene 10c (Table 5, entry 3). Under these conditions, alkynes $9 \mathbf{a}$ and $9 \mathbf{b}$ produced an unseparable mixture of some products. To our delight, treating $9 \mathbf{a}$ and $9 \mathbf{b}$ with triflic acid in $\mathrm{CH}_{2} \mathrm{Cl}_{2}$ solution at room temperature allowed us to obtain helicenes 10a and 10b in high yields (Table 5, entries 1 and 2). Apparently, the presence of the aza group adjacent to the triple bond in compounds $9 \mathbf{a}$ and $\mathbf{9 b}$ causes the observed difference in the reactivity of compounds $\mathbf{9}$. Its protonation makes the formation of a key cyclization intermediate $\mathbf{1 1}$ difficult.

It is known that the $[n]$ helicenes with at least one five-membered heteroaromatic ring need $n \geq 6$ to become intrinsically chiral $[9,10]$. High-performance liquid chromatography on chiral stationary phases confirmed the presence of configurationally stable $(P)$ - and $(M)$-enantiomers at room temperature in the samples of synthesized helicenes 10a-c. In all cases, separation of enantiomers of $\mathbf{1 0}$ was achieved using Kromasil 5-Cellucoat column $(4.6 \mathrm{~mm} \times 250 \mathrm{~mm})$, acetonitrile as a mobile phase and UV-detection (see Supporting Information File 1, Figures S38-S40).

\section{X-ray molecular structures}

The structures of the title compounds $\mathbf{1 0 a}-\mathbf{c}$ were further explored by a single-crystal X-ray diffraction analysis (Figure 1, see also Supporting Information File 1, Figures S35-S37 and Table S1) and compared with that of the carbazole-based [6]helicene [42] (7-hexyl-7H-phenanthro[3,4$c$ carbazole, 12) to see the effect of the azine ring annelation (Table 6).

Table 5: Acid-induced isomerization of compounds 9 into carbazole-based [6]helicenes 10.

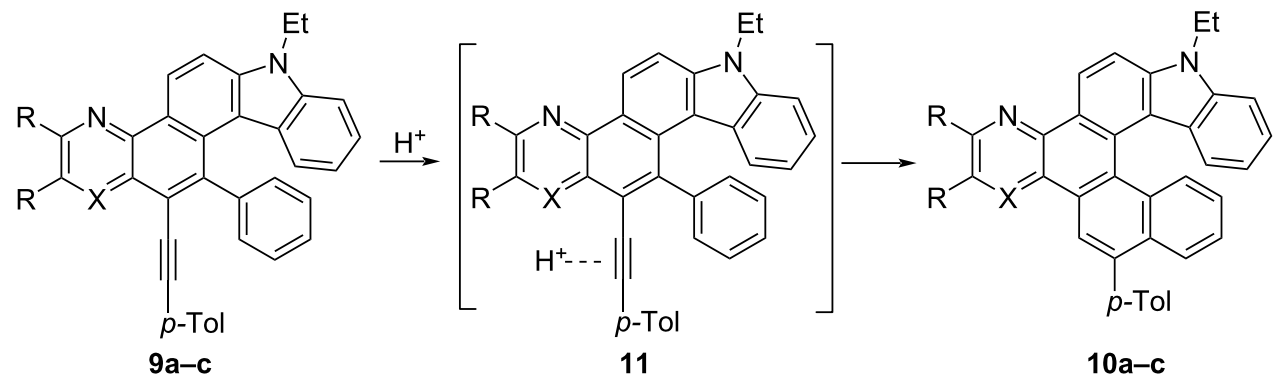

\begin{tabular}{cccccc}
\hline Entry & $\mathrm{X}$ & $\mathrm{R}, \mathrm{R}$ & Conditions & Product & Yield,\% \\
\hline 1 & $\mathrm{~N}$ & $-(\mathrm{CH}=\mathrm{CH})_{2}-$ & $\mathrm{CF}_{3} \mathrm{SO}_{3} \mathrm{H}, \mathrm{CH}_{2} \mathrm{Cl}_{2}, \mathrm{rt}, 24 \mathrm{~h}$, dark & $\mathbf{1 0 a}$ & 92 \\
2 & $\mathrm{~N}$ & $\mathrm{H}, \mathrm{H}$ & $\mathrm{CF}_{3} \mathrm{SO}_{3} \mathrm{H}, \mathrm{CH}_{2} \mathrm{Cl}_{2}, \mathrm{rt}, 24 \mathrm{~h}$, dark & $\mathbf{1 0 b}$ & 82 \\
3 & $\mathrm{CH}$ & $\mathrm{H}, \mathrm{H}$ & $\mathrm{CF}_{3} \mathrm{CO}_{2} \mathrm{H}, 85^{\circ} \mathrm{C}, 24 \mathrm{~h}$ & $\mathbf{1 0 c}$ & 94
\end{tabular}




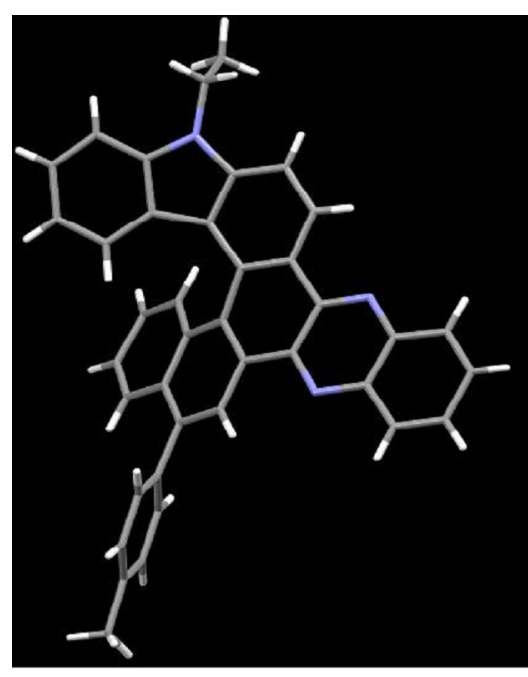

a

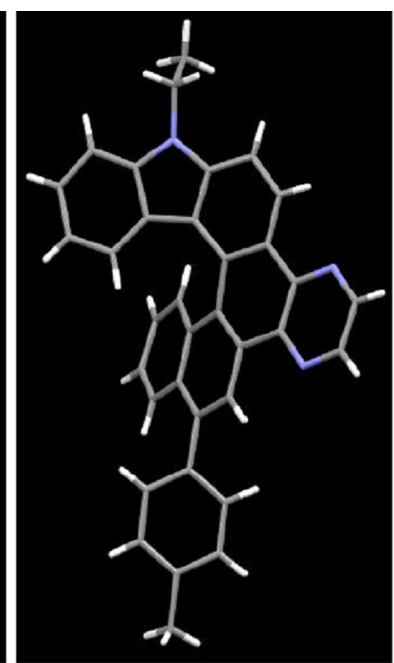

b

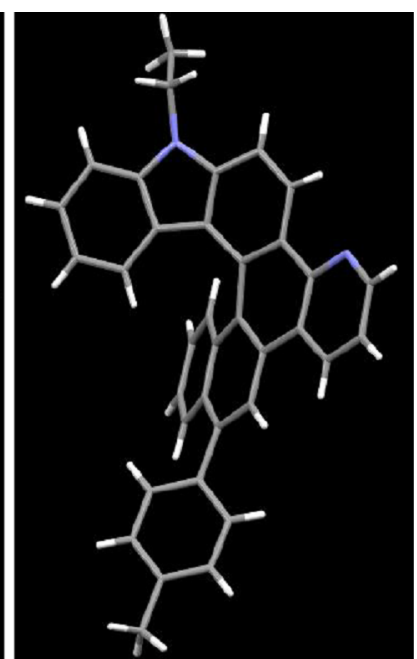

c

Figure 1: Molecular structure of carbazole-based [6]helicenes 10a (a), 10b (b) and 10c (c) (X-ray data).

The values of the torsion and interplanar angles make it possible to describe and compare the structural specificity of the synthesized [6]helicenes. From the data given in Table 6, it can be seen that the interplanar angle between the terminal rings $A$ and $\mathrm{F}$ of the pyridine-fused [6]helicene 10c is the largest in the series (average value is $62^{\circ}$ ). The same value for [6]helicene $\mathbf{1 2}$ is equal to $56.7^{\circ}[42]$. The helicity of pyrazine-fused [6] helicene 10b and quinoxaline-fused hybrid 10a is intermediate $\left(52.8^{\circ}\right.$ and $50.5^{\circ}$ ). Comparing the sum of the inner helix torsion angles of the helicenes $\mathbf{1 0 a}-\mathbf{c}$ and $\mathbf{1 2}$ reveals the same patterns. Evidently, the repulsive interaction of the $\mathrm{H}(14)$ and $\mathrm{H}(\mathrm{g})$ atoms of $10 \mathbf{c}$ is the main reason for the observed extra twisting, whereas relative planarization of $\mathbf{1 0 a}$ and $\mathbf{1 0 b}$ is the result of attractive interactions of the aza groups $\mathrm{N}(\mathrm{f})$ and $\mathrm{N}(\mathrm{g})$ with the $\mathrm{H}(9)$ and $\mathrm{H}(14)$ atoms, respectively. The short intramolecular contacts $\mathrm{H}(9) \cdots \mathrm{N}(\mathrm{f})(2.457 \AA$ for $\mathbf{1 0 a}, 2.454 \AA$ for $\mathbf{1 0 b})$ and $\mathrm{H}(14) \cdots \mathrm{N}(\mathrm{g})(2.517 \AA$ for $\mathbf{1 0 a}, 2.477 \AA$ for $\mathbf{1 0 b})$ support this opinion. Apparently, interaction of this type is also realized in solution since the signal of the inner helix proton in the ${ }^{1} \mathrm{H}$ NMR spectra of azine-fused [6]helicenes appeared in the low field at $\delta$ 9.3-9.7 ppm. A similar pattern was observed by us in the structures of the azine-fused [5]helicenes [72].

It is well-known that the inner helix and outer helix $\mathrm{C}-\mathrm{C}$ bonds of helicenes differ in their length [9]. Deviations of some of them from the standard aromatic $\mathrm{C}-\mathrm{C}$ bond of benzene $(1.393 \AA)$ are significant. The length of the inner helix C-C bonds of [6] helicene $\mathbf{1 2}$ varies from 1.400 to $1.459 \AA$. On the contrary, the outer helix bonds of $\mathbf{1 2}$ are noticeably shortened (1.330-1.368 $\AA$ ). The same tendency is observed in cases of azine-fused [6]helicenes 10. Their inner helix bonds are some- what lengthened: $1.403-1.470 \AA$ (for 10a), 1.408-1.462 $\AA$ (for 10b), 1.402-1.466 $\AA$ (for 10c). The shortest outer helix bonds of helicenes $\mathbf{1 0}$ are $1.369 \AA$ (10a), $1.369 \AA$ (10b) and $1.364 \AA$ (10c). The maximum deviation from the standard value was recorded for the $\mathrm{C}-\mathrm{C}$ bonds of the central $\mathrm{D}$ ring of the [6]helicenes 10a-c. In particular, the $\mathrm{C}(\mathrm{c})-\mathrm{C}(\mathrm{d})$ length of quinoxaline-fused helicene 10a (1.470 $\AA$ ) practically does not differ in its length from the standard single $\mathrm{C}\left(\mathrm{sp}^{2}\right)-\mathrm{C}\left(\mathrm{sp}^{2}\right)$ bond (ca. $1.48 \AA$ ).

The X-ray analysis of quinoxaline-fused [6]helicene 10a revealed the presence of the face-to-face $\pi-\pi$ interaction between the helicene aggregates. The racemic aggregation was composed by $(P)$ - and $(M)$-enantiomers on the manner of embrace: $\pi$-deficient pyrazine ring of one enantiomer of $\mathbf{1 0 a}$ is located over the $\pi$-excessive pyrrole ring of another enantiomer (Figure 2a and Figure 2b). An intermolecular distance between the centroids of these rings was found to be equal to $3.74 \AA$ making the $\pi$ overlapping possible. In the case of helicene $\mathbf{1 0 b}$, the enantiomeric molecules are aggregated into pairs differently: the pyrazine ring of one enantiomer is located over the $E$ ring of another enantiomer and the distance between the layers is ca. $3.4 \AA$ (Figure $2 \mathrm{c}$ and Figure $2 \mathrm{~d}$ ). The crystal packing of helicene 10c (Figure 2e) is peculiar: the alternating enantiomers form a screw along the $a$ axis.

\section{Optical properties}

All helicenes $\mathbf{1 0}$ are well soluble in dichloromethane and chloroform. Solubility in other common solvents such as acetonitrile, DMSO, tetrahydrofuran, ethanol and hexane is markedly lower. Carbazole-based [6] helicene $\mathbf{1 2}$ was described as yellow 
Table 6: Comparison of X-ray data of the carbazole-based [6]helicenes (atomic numbering does not correspond to IUPAC nomenclature).

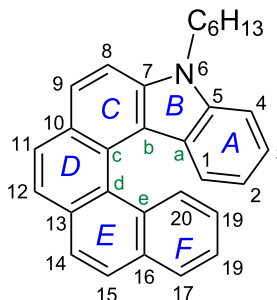

12

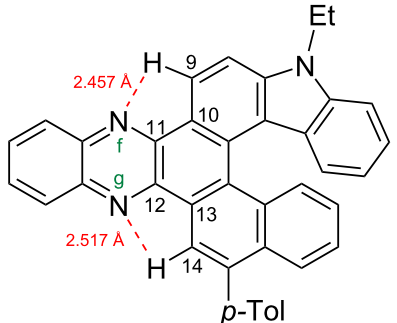

$10 \mathrm{a}$

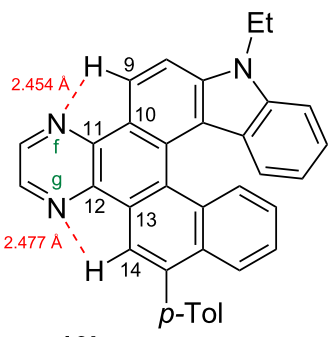

$10 \mathrm{~b}$

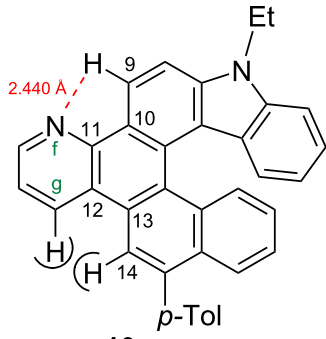

$10 \mathrm{c}$

\begin{tabular}{|c|c|c|c|c|c|c|c|}
\hline \multirow[t]{3}{*}{ Helicene } & \multirow{3}{*}{$\begin{array}{l}\text { Space } \\
\text { group }\end{array}$} & \multicolumn{2}{|c|}{ Bond length, ^̊ } & \multirow{2}{*}{$\begin{array}{l}\text { Inner helix } \\
\text { angle, }{ }^{\circ}\end{array}$} & \multicolumn{2}{|c|}{ Torsion angle ${ }^{a}, o$} & \multirow{2}{*}{$\begin{array}{l}\text { Interplanar } \\
\text { angle }^{\mathrm{b}},{ }^{\circ}\end{array}$} \\
\hline & & Inner helix & Ring D & & & & \\
\hline & & $\begin{array}{l}1-a \\
a-b \\
b-c \\
c-d \\
d-e \\
e-20\end{array}$ & $\begin{array}{c}10-11 \\
11-12 \\
12-13 \\
13-d \\
d-c \\
c-10\end{array}$ & $\begin{array}{c}1-a-b \\
a-b-c \\
b-c-d \\
c-d-e \\
d-e-20\end{array}$ & $\begin{array}{l}1-a-b-c \\
a-b-c-d \\
b-c-d-e \\
c-d-e-20\end{array}$ & $\begin{array}{c}9-10-11-f \\
g-12-13-14\end{array}$ & $A / F$ \\
\hline 12 [42] & $P 2_{1} / C$ & $\begin{array}{c}1.401 \\
1.434 \\
1.423 \\
1.448 \\
1.459 \\
1.400 \\
(8.565 \\
\text { in total) }\end{array}$ & $\begin{array}{c}1.391 \\
1.343 \\
1.434 \\
1.407 \\
1.448 \\
1.435 \\
(8.458 \\
\text { in total) }\end{array}$ & $\begin{array}{c}135.4 \\
135.3 \\
126.2 \\
124.6 \\
122.3 \\
(643.8 \\
\text { in total) }\end{array}$ & $\begin{array}{c}0.8 \\
17.8 \\
32.2 \\
16.9 \\
(67.7 \\
\text { in total) }\end{array}$ & - & 56.7 \\
\hline $10 a$ & $P 2_{1} / C$ & $\begin{array}{c}1.403 \\
1.457 \\
1.423 \\
1.470 \\
1.441 \\
1.415 \\
(8.609 \\
\text { in total) }\end{array}$ & $\begin{array}{c}1.457 \\
1.443 \\
1.462 \\
1.396 \\
1.470 \\
1.413 \\
(8.641 \\
\text { in total) }\end{array}$ & $\begin{array}{c}135.7 \\
135.4 \\
125.0 \\
123.3 \\
121.4 \\
\text { (640.8 } \\
\text { in total) }\end{array}$ & $\begin{array}{c}3.1 \\
10.7 \\
37.8 \\
15.6 \\
(67.2 \\
\text { in total) }\end{array}$ & $\begin{array}{l}7.6 \\
2.4\end{array}$ & 50.5 \\
\hline $10 b^{c}$ & $P 2_{1} / n$ & $\begin{array}{c}1.408 \\
1.456 \\
1.430 \\
1.464 \\
1.442 \\
1.417 \\
(8.721 \\
\text { in total) } \\
(8.617 \\
\text { in total) }^{*}\end{array}$ & $\begin{array}{c}1.449 \\
1.412 \\
1.451 \\
1.400 \\
1.464 \\
1.418 \\
(8.594 \\
\text { in total) } \\
\text { (8.596 }^{\text {in total) }}\end{array}$ & $\begin{array}{c}135.8 \\
135.6 \\
125.3 \\
123.7 \\
121.0 \\
(641.4 \\
\text { in total) } \\
(640.6 \\
\text { in total)* }\end{array}$ & $\begin{array}{c}0.8 \\
11.3 \\
32.3 \\
21.6 \\
(65.7 \\
\text { in total) } \\
(68.4 \\
\text { in total)* }\end{array}$ & $\begin{array}{l}5.3 \\
2.4 \\
3.2^{*} \\
2.0^{*}\end{array}$ & $\begin{array}{c}50.6 \\
53.7^{\star}\end{array}$ \\
\hline $10 c^{a}$ & $P_{c a 2}$ & $\begin{array}{c}1.402 \\
1.466 \\
1.435 \\
1.452 \\
1.450 \\
1.418 \\
(8.623 \\
\text { in total) } \\
(8.603 \\
\text { in total)* }\end{array}$ & $\begin{array}{c}1.461 \\
1.411 \\
1.451 \\
1.401 \\
1.452 \\
1.414 \\
(8.590 \\
\text { in total) } \\
\text { (8.605 }^{\text {(8) total)* }}\end{array}$ & $\begin{array}{c}135.6 \\
134.9 \\
125.0 \\
123.5 \\
121.1 \\
(640.1 \\
\text { in total) } \\
(640.8 \\
\text { in total)* }\end{array}$ & $\begin{array}{c}3.0 \\
14.0 \\
33.9 \\
22.7 \\
(73.6 \\
\text { in total) } \\
(72.3 \\
\text { in total)* }\end{array}$ & $\begin{array}{l}0.9 \\
3.3 \\
0.7^{\star} \\
3.4^{*}\end{array}$ & $\begin{array}{l}62.3 \\
61.6^{*}\end{array}$ \\
\hline
\end{tabular}

${ }^{\mathrm{a}} \mathrm{A}$ dihedral angle between the four adjacent inner helix carbon atoms. ${ }^{\mathrm{b}} \mathrm{An}$ angle between the two terminal aromatic rings $\mathrm{A}$ and $\mathrm{F}$ of a helicene. ${ }^{\mathrm{C}}$ There are two independent molecules in the unit cell. Data for the second molecule are marked with an asterisk *. 


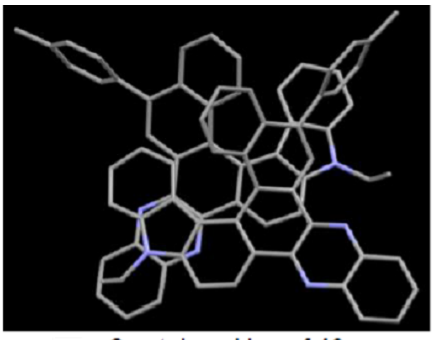

a - Crystal packing of $10 a$ (aggregate of $(\mathrm{P})$ - and $(\mathrm{M})$ enantiomers)

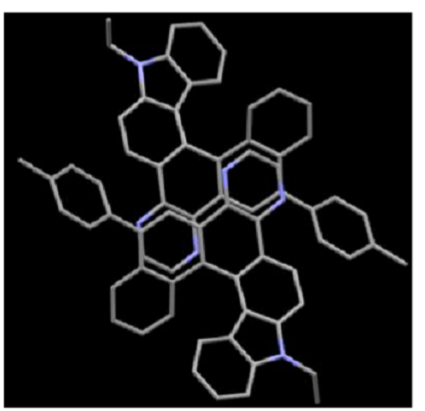

c - Crystal packing of $10 \mathrm{~b}$ (aggregate of $(P)$ - and (M)enantiomers)

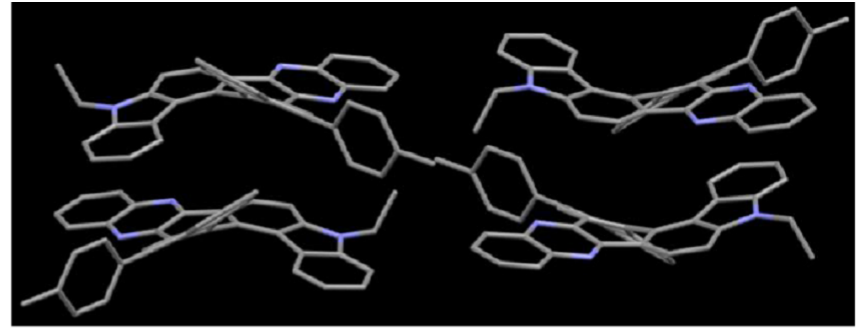

$b-$ Crystal packing of $10 a$

(view along the $a$ axis)

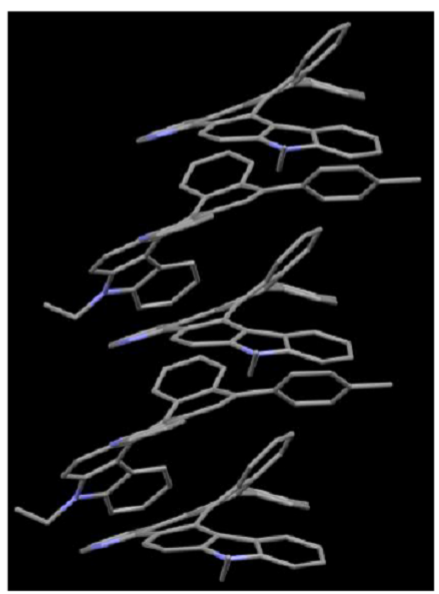

e-Crystal packing of $10 \mathrm{c}$ (view along the a axis)

Figure 2: Crystal packing of carbazole-based [6]helicenes $10 a(a, b), 10 b(c, d)$ and 10c (e). Hydrogen atoms are hidden.

solid (the longest $\lambda_{\max } 414 \mathrm{~nm}, \mathrm{CH}_{2} \mathrm{Cl}_{2}$ ) [42]. All azine-fused analogs of $\mathbf{1 2}$ are yellow-orange. The annelation of the pyridine or pyrazine ring to the skeleton of $\mathbf{1 2}$ only slightly changed the wavelength of the absorption maximum (the longest $\lambda_{\max } 411$ and $418 \mathrm{~nm}$, respectively), whereas the absorption of quinoxaline-fused [6] helicene 10a was red-shifted by $19 \mathrm{~nm}$ (Table 7). Compounds 10 exhibited almost a solvent independence of UV-vis absorption spectra (Supporting Information File 1, Figure S41). The optical band gaps $\left(E_{\mathrm{g}}{ }^{\text {opt }}\right)$, estimated from the onset point of the absorption spectra, for [6]helicene $\mathbf{1 2}$ was equal to $2.92 \mathrm{eV}$ [42]. The $E_{\mathrm{g}}$ opt values for its $\pi$-extended analogs were $2.45 \mathrm{eV}$ (10a), $2.76 \mathrm{eV}$ (10b) and $2.85 \mathrm{eV}$ (10c), suggesting a higher HOMO and lower oxidation potential, which are typically desired characteristics when designing organic materials. Unfortunately, for all azine-fused [6]helicenes 10 only weak fluorescence in the solution under UV irradiation was observed (Table 7, see also Supporting Information File 1, Figures S42-S45). Helicenes 10b and 10c

Table 7: Photophysical properties of carbazole-based [6]helicenes 10.

\begin{tabular}{|c|c|c|c|c|c|c|}
\hline \multirow[t]{2}{*}{ Compd. } & \multicolumn{2}{|l|}{ Absorption $\left(\mathrm{CH}_{2} \mathrm{Cl}_{2}\right)^{\mathrm{a}}$} & \multirow[t]{2}{*}{$E_{\mathrm{g}}^{\mathrm{opt}}, \mathrm{eV}^{\mathrm{b}}$} & \multicolumn{3}{|c|}{ Absorption and emission ${ }^{\mathrm{C}}\left(\mathrm{CH}_{3} \mathrm{CN}\right)$} \\
\hline & $\lambda_{\max }, \mathrm{nm}$ & $\lambda_{\text {onset }}, \mathrm{nm}$ & & $\lambda_{\mathrm{abs}}, \mathrm{nm}^{\mathrm{d}}$ & $\lambda_{\text {em }}, \mathrm{nm}$ & Stokes shift, $\mathrm{nm}$ \\
\hline $12[42]$ & 282,320, sh $347,393,414$ & 425 & 2.92 & 414 & 426 & 12 \\
\hline $10 a$ & 264,303, sh $324,357,374,433$ & 507 & 2.45 & 433 & 561 & 128 \\
\hline $10 b$ & $294,323,359,397,418$ & 449 & 2.76 & 418 & 481 & 63 \\
\hline $10 c$ & 265,285 , sh $306,324,371$, sh 388,411 & 435 & 2.85 & 410 & 440 & 30 \\
\hline
\end{tabular}

aAssorption maxima measured in $\approx 10^{-5} \mathrm{M}$ solution, abbreviation "sh" means shoulder. ${ }^{\text {b}}$ The optical gap was estimated from the onset point of the

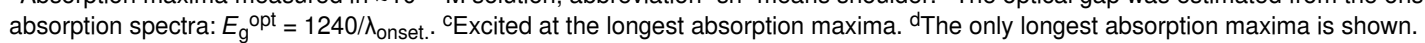


exhibited blue emission with emission peaks at 481 and $440 \mathrm{~nm}$, respectively. Quinoxaline-fused helicene 10a demonstrated a yellow emission with the highest in the series $\lambda_{\mathrm{em}}=561 \mathrm{~nm}$ and Stokes shift $128 \mathrm{~nm}$.

\section{Conclusion}

In summary, novel carbazole-based [6]helicenes fused with an azine ring (pyridine, pyrazine or quinoxaline) have been prepared from commercially available 2,3-dihaloazines via a fivestep synthetic sequence. Two key steps of the method are electrophile-induced 6-endo-dig cyclizations of ortho-alkynylated biaryls. The overall yields of helicenes in five stages of the synthesis exceed $30 \%$.

The single-crystal X-ray diffraction analysis revealed the nonplanar crystal structures of the synthesized helicenes responsible for reducing close-packing arrangement, though, in cases of pyrazine- and quinoxaline-fused helicenes, moderate $\pi$ overlap in pairs of enantiomeric molecules was observed. Carbazolebased [6]helicene, fused with the pyridine ring, is more twisted than the parent carbazole-based [6]helicene $(7 \mathrm{H}$ phenanthro[3,4-c]carbazole). The interplanar angle between the two terminal benzene rings of the latter is equal to $56.7^{\circ}$, whereas the same value for the pyridine-fused analog is $62^{\circ}$. The pyrazine-fused [6]helicene demonstrates intermediate helicity $\left(52.8^{\circ}\right)$. In the case of the quinoxaline-fused analog the distortion angle of $50.5^{\circ}$ is the smallest in the series.

The photophysical properties of the synthesized [6]helicenes were compared to the parent carbazole-based [6]helicene. A spectrophotometric analysis of the quinoxaline-fused helicene displayed a moderate absorption red-shift (19 nm) and reduced optical band gaps (by $\approx 0.5 \mathrm{eV}$ ). In cases of pyrazine and pyridine-fused analogs, differences are not so noticeable.

\section{Experimental}

The synthetic procedures, HPLC, X-ray studies and spectra $\left({ }^{1} \mathrm{H}\right.$ and ${ }^{13} \mathrm{C}$ NMR) of all new compounds can be found in Supporting Information File 1.

\section{Supporting Information}

\section{Supporting Information File 1}

Experimental procedures and analytical data, copies of ${ }^{1} \mathrm{H}$ and ${ }^{13} \mathrm{C}$ NMR spectra of all new compounds, X-ray data for $9 \mathbf{c}$ and 10a-c, HPLC spectra of helicenes 10a-c, UV-vis and fluorescence spectra of $\mathbf{1 0 a - c}$. [https://www.beilstein-journals.org/bjoc/content/ supplementary/1860-5397-17-2-S1.pdf]

\section{Acknowledgements}

The authors thank Drs. Anna V. Tkachuk and Oleg N. Burov (Scientific and Educational Laboratory of Resonance Spectroscopy, Department of Natural and High Molecular Compounds Chemistry, Southern Federal University) for NMR measurements. We also thank Daria V. Spiridonova and Dr. Alexander D. Misharev for X-ray studies and HRMS measurements (Centre for X-ray Diffraction Studies and Chemical Analysis and Materials Research Centre, Institute of Chemistry, St. Petersburg State University).

\section{Funding}

The authors gratefully acknowledge the Russian Foundation for Basic Research (grant No 18-03-00006) for financial support of this research.

\section{ORCID ${ }^{\circledR} \mathrm{iDs}$}

Daria I. Tonkoglazova - https://orcid.org/0000-0002-1643-3471

Anna V. Gulevskaya - https://orcid.org/0000-0002-5356-3267

\section{References}

1. Shen, Y.; Chen, C.-F. Chem. Rev. 2012, 112, 1463-1535. doi:10.1021/cr200087r

2. Gingras, M. Chem. Soc. Rev. 2013, 42, 968-1006. doi:10.1039/c2cs35154d

3. Gingras, M.; Félix, G.; Peresutti, R. Chem. Soc. Rev. 2013, 42, 1007-1050. doi:10.1039/c2cs35111k

4. Gingras, M. Chem. Soc. Rev. 2013, 42, 1051-1095. doi:10.1039/c2cs35134j

5. Dumitrascu, F.; Dumitrescu, D. G.; Aron, I. ARKIVOC 2009, No. 1, 1-32. doi:10.3998/ark.5550190.0011.101

6. Saleh, N.; Shen, C.; Crassous, J. Chem. Sci. 2014, 5, 3680-3694. doi:10.1039/c4sc01404a

7. Shigeno, M.; Kushida, Y.; Yamaguchi, M. Chem. Commun. 2016, 52, 4955-4970. doi:10.1039/c5cc10379g

8. Isla, H.; Crassous, J. C. R. Chim. 2016, 19, 39-49. doi:10.1016/j.crci.2015.06.014

9. Chen, C.-F.; Shen, Y. Helicene Chemistry: From Synthesis to Applications; Springer: Berlin, Heidelberg, Germany, 2017. doi:10.1007/978-3-662-53168-6

10. Hasan, M.; Borovkov, V. Symmetry 2018, 10, No. 10. doi:10.3390/sym 10010010

11. Rickhaus, M.; Mayor, M.; Juríček, M. Chem. Soc. Rev. 2016, 45, 1542-1556. doi:10.1039/c5cs00620a

12. Rulíšek, L.; Exner, O.; Cwiklik, L.; Jungwirth, P.; Starý, I.; Pospíšil, L.; Havlas, Z. J. Phys. Chem. C 2007, 111, 14948-14955. doi:10.1021/jp075129a

13. Hrbac, J.; Storch, J.; Halouzka, V.; Cirkva, V.; Matejka, P.; Vacek, J. RSC Adv. 2014, 4, 46102-46105. doi:10.1039/c4ra06283c

14. Vacek, J.; Vacek Chocholoušová, J.; Stará, I. G.; Starý, I.; Dubi, Y. Nanoscale 2015, 7, 8793-8802. doi:10.1039/c5nr01297j

15. Fujikawa, T.; Mitoma, N.; Wakamiya, A.; Saeki, A.; Segawa, Y.; Itami, K. Org. Biomol. Chem. 2017, 15, 4697-4703. doi:10.1039/c7ob00987a 
16. Verbiest, T.; van Elshocht, S.; Kauranen, M.; Hellemans, L.; Snauwaert, J.; Nuckolls, C.; Katz, T. J.; Persoons, A. Science 1998, 282, 913-915. doi:10.1126/science.282.5390.913

17. Coe, B. J.; Rusanova, D.; Joshi, V. D.; Sánchez, S.; Vávra, J.; Khobragade, D.; Severa, L.; Císařová, I.; Šaman, D.; Pohl, R.; Clays, K.; Depotter, G.; Brunschwig, B. S.; Teplý, F. J. Org. Chem. 2016, 81, 1912-1920. doi:10.1021/acs.joc.5b02692

18. Phillips, K. E. S.; Katz, T. J.; Jockusch, S.; Lovinger, A. J.; Turro, N. J. J. Am. Chem. Soc. 2001, 123, 11899-11907. doi:10.1021/ja011706b

19. Field, J. E.; Muller, G.; Riehl, J. P.; Venkataraman, D. J. Am. Chem. Soc. 2003, 125, 11808-11809. doi:10.1021/ja035626e

20. Sawada, Y.; Furumi, S.; Takai, A.; Takeuchi, M.; Noguchi, K.; Tanaka, K. J. Am. Chem. Soc. 2012, 134, 4080-4083. doi:10.1021/ja300278e

21. Shyam Sundar, M.; Talele, H. R.; Mande, H. M.; Bedekar, A. V.; Tovar, R. C.; Muller, G. Tetrahedron Lett. 2014, 55, 1760-1764. doi:10.1016/j.tetlet.2014.01.108

22. Nakamura, K.; Furumi, S.; Takeuchi, M.; Shibuya, T.; Tanaka, K. J. Am. Chem. Soc. 2014, 136, 5555-5558. doi:10.1021/ja500841f

23. Yamamoto, Y.; Sakai, H.; Yuasa, J.; Araki, Y.; Wada, T.; Sakanoue, T.; Takenobu, T.; Kawai, T.; Hasobe, T. Chem. - Eur. J. 2016, 22 , 4263-4273. doi:10.1002/chem.201504048

24. Yamamoto, Y.; Sakai, H.; Yuasa, J.; Araki, Y.; Wada, T.; Sakanoue, T.; Takenobu, T.; Kawai, T.; Hasobe, T. J. Phys. Chem. C 2016, 120, 7421-7427. doi:10.1021/acs.jpcc.6b01123

25. Ben Hassine, B.; Gorsane, M.; Pecher, J.; Martin, R. H. Bull. Soc. Chim. Belg. 1986, 95, 557-566. doi:10.1002/bscb.19860950706

26. Reetz, M. T.; Beuttenmüller, E. W.; Goddard, R. Tetrahedron Lett. 1997, 38, 3211-3214. doi:10.1016/s0040-4039(97)00562-5

27. Takenaka, N.; Sarangthem, R. S.; Captain, B. Angew. Chem., Int. Ed. 2008, 47, 9708-9710. doi:10.1002/anie.200803338

28. Aillard, P.; Voituriez, A.; Marinetti, A. Dalton Trans. 2014, 43, 15263-15278. doi:10.1039/c4dt01935k

29. Dova, D.; Viglianti, L.; Mussini, P. R.; Prager, S.; Dreuw, A.; Voituriez, A.; Licandro, E.; Cauteruccio, S. Asian J. Org. Chem. 2016, 5, 537-549. doi:10.1002/ajoc.201600025

30. Fujikawa, T.; Segawa, Y.; Itami, K. J. Am. Chem. Soc. 2016, 138, 3587-3595. doi:10.1021/jacs.6b01303

31. Huang, Q.; Jiang, L.; Liang, W.; Gui, J.; Xu, D.; Wu, W.; Nakai, Y.; Nishijima, M.; Fukuhara, G.; Mori, T.; Inoue, Y.; Yang, C. J. Org. Chem. 2016, 81, 3430-3434. doi:10.1021/acs.joc.6b00130

32. Tounsi, M.; Ben Braiek, M.; Baraket, A.; Lee, M.; Zine, N.; Zabala, M.; Bausells, J.; Aloui, F.; Ben Hassine, B.; Maaref, A.; Errachid, A. Electroanalysis 2016, 28, 2892-2899. doi:10.1002/elan.201600104

33. Xu, Y.; Zhang, Y. X.; Sugiyama, H.; Umano, T.; Osuga, H.; Tanaka, K. J. Am. Chem. Soc. 2004, 126, 6566-6567. doi:10.1021/ja0499748

34. Passeri, R.; Aloisi, G. G.; Elisei, F.; Latterini, L.; Caronna, T.; Fontana, F.; Sora, I. N. Photochem. Photobiol. Sci. 2009, 8, 1574-1582. doi:10.1039/b9pp00015a

35. Kelber, J.; Achard, M.-F.; Durola, F.; Bock, H. Angew. Chem., Int. Ed. 2012, 51, 5200-5203. doi:10.1002/anie.201108886

36. Xiao, S.; Kang, S. J.; Wu, Y.; Ahn, S.; Kim, J. B.; Loo, Y.-L.; Siegrist, T.; Steigerwald, M. L.; Li, H.; Nuckolls, C. Chem. Sci. 2013, 4, 2018-2023. doi:10.1039/c3sc50374g

37. Bédard, A.-C.; Vlassova, A.; Hernandez-Perez, A. C.; Bessette, A.; Hanan, G. S.; Heuft, M. A.; Collins, S. K. Chem. - Eur. J. 2013, 19, 16295-16302. doi:10.1002/chem.201301431

38. Meisenheimer, J.; Witte, K. Ber. Dtsch. Chem. Ges. 1903, 36, 4153-4164. doi:10.1002/cber.19030360481
39. Ben Braiek, M.; Aloui, F.; Moussa, S.; Tounsi, M.; Marrot, J.; Ben Hassine, B. Tetrahedron Lett. 2013, 54, 5421-5425. doi:10.1016/j.tetlet.2013.07.036

40. Upadhyay, G. M.; Bedekar, A. V. Tetrahedron 2015, 71, 5644-5649. doi:10.1016/j.tet.2015.06.040

41. Al Mousawi, A.; Dumur, F.; Garra, P.; Toufaily, J.; Hamieh, T.; Goubard, F.; Bui, T.-T.; Graff, B.; Gigmes, D.; Pierre Fouassier, J.; Lalevée, J. J. Polym. Sci., Part A: Polym. Chem. 2017, 55, 1189-1199. doi:10.1002/pola.28476

42. Hua, W.; Liu, Z.; Duan, L.; Dong, G.; Qu, Y.; Zhang, B.; Cui, D.; Tao, X.; Cheng, N.; Liu, Y. RSC Adv. 2015, 5, 75-84. doi:10.1039/c4ra13486a

43. Kötzner, L.; Webber, M. J.; Martínez, A.; DeFusco, C.; List, B. Angew. Chem., Int. Ed. 2014, 53, 5202-5205. doi:10.1002/anie.201400474

44. Luo, X.-Y.; Liu, Z.; Zhang, B.-J.; Hua, W.-M.; Feng, Y.; Li, L.; Zhang, D.-C.; Cui, D.-L. ChemistrySelect 2018, 3, 3426-3432. doi:10.1002/slct.201800267

45. Nakano, K.; Hidehira, Y.; Takahashi, K.; Hiyama, T.; Nozaki, K. Angew. Chem., Int. Ed. 2005, 44, 7136-7138. doi:10.1002/anie.200502855

46. Upadhyay, G. M.; Talele, H. R.; Bedekar, A. V. J. Org. Chem. 2016, 81, 7751-7759. doi:10.1021/acs.joc.6b01395

47. Bucinskas, A.; Waghray, D.; Bagdziunas, G.; Thomas, J.; Grazulevicius, J. V.; Dehaen, W. J. Org. Chem. 2015, 80, 2521-2528. doi:10.1021/jo5024188

48. Ben Braiek, M.; Aloui, F.; Ben Hassine, B. Tetrahedron Lett. 2016, 57, 2763-2766. doi:10.1016/j.tetlet.2016.05.030

49. Dreher, S. D.; Weix, D. J.; Katz, T. J. J. Org. Chem. 1999, 64, 3671-3678. doi:10.1021/jo990065o

50. Shi, L.; Liu, Z.; Dong, G.; Duan, L.; Quu, Y.; Jia, J.; Guo, W.; Zhao, D.; Cui, D.; Tao, X. Chem. - Eur. J. 2012, 18, 8092-8099. doi:10.1002/chem.201200068

51. Upadhyay, G. M.; Talele, H. R.; Sahoo, S.; Bedekar, A. V. Tetrahedron Lett. 2014, 55, 5394-5399. doi:10.1016/j.tetlet.2014.07.116

52. Jiang, H.; Sun, J.; Zhang, J. Curr. Org. Chem. 2012, 16, 2014-2025. doi:10.2174/138527212803251604

53. Ziarani, G. M.; Moradi, R.; Lashgari, N.; Kruger, H. G. Carbazole Dyes. Metal-Free Synthetic Organic Dyes; Elsevier: Amsterdam, Netherlands, 2018; pp 109-116. doi:10.1016/b978-0-12-815647-6.00006-6

54. D'Ischia, M.; Napolitano, A.; Pezzella, A. Pyrroles and their Benzo Derivatives: Applications. In Comprehensive Heterocyclic Chemistry III; Katritzky, A. R.; Ramsden, C. A.; Scriven, E. F. V.; Taylor, R. J. K., Eds.; Elsevier Science, 2008; Vol. 3, pp 353-388. doi:10.1016/b978-008044992-0.00304-7

55. Chan, G. W.; Francis, T.; Thureen, D. R.; Offen, P. H.; Pierce, N. J.; Westley, J. W.; Johnson, R. K.; Faulkner, D. J. J. Org. Chem. 1993, 58, 2544-2546. doi:10.1021/jo00061a031

56. Hamasaki, A.; Zimpleman, J. M.; Hwang, I.; Boger, D. L. J. Am. Chem. Soc. 2005, 127, 10767-10770. doi:10.1021/ja0526416

57. Baryshnikov, G. V.; Gawrys, P.; Ivaniuk, K.; Witulski, B.; Whitby, R. J.; Al-Muhammad, A.; Minaev, B.; Cherpak, V.; Stakhira, P.; Volyniuk, D.; Wiosna-Salyga, G.; Luszczynska, B.; Lazauskas, A.; Tamulevicius, S.; Grazulevicius, J. V. J. Mater. Chem. C 2016, 4, 5795-5805. doi:10.1039/c6tc01469k

58. Weimar, M.; Correa da Costa, R.; Lee, F.-H.; Fuchter, M. J. Org. Lett. 2013, 15, 1706-1709. doi:10.1021/ol400493x

59. Carreras, J.; Patil, M.; Thiel, W.; Alcarazo, M. J. Am. Chem. Soc. 2012, 134, 16753-16758. doi:10.1021/ja306947m 
60. Frigoli, M.; Marrot, J.; Gentili, P. L.; Jacquemin, D.; Vagnini, M.; Pannacci, D.; Ortica, F. ChemPhysChem 2015, 16, 2447-2458. doi:10.1002/cphc.201500251

61. Li, Y.; Waser, J. Angew. Chem., Int. Ed. 2015, 54, 5438-5442. doi:10.1002/anie.201412321

62. Oyama, H.; Nakano, K.; Harada, T.; Kuroda, R.; Naito, M.; Nobusawa, K.; Nozaki, K. Org. Lett. 2013, 15, 2104-2107. doi:10.1021/ol4005036

63. Hirano, K.; Inaba, Y.; Takasu, K.; Oishi, S.; Takemoto, Y.; Fujii, N.; Ohno, H. J. Org. Chem. 2011, 76, 9068-9080. doi:10.1021/jo2018119

64. Yao, T.; Campo, M. A.; Larock, R. C. J. Org. Chem. 2005, 70, 3511-3517. doi:10.1021/j0050104y

65. Mohamed, R. K.; Mondal, S.; Guerrera, J. V.; Eaton, T. M.; Albrecht-Schmitt, T. E.; Shatruk, M.; Alabugin, I. V. Angew. Chem., Int. Ed. 2016, 55, 12054-12058. doi:10.1002/anie.201606330

66. Storch, J.; Cermak, J.; Karban, J.; Cisarova, I.; Sykora, J. J. Org. Chem. 2010, 75, 3137-3140. doi:10.1021/jo100252a

67. Mandadapu, A. K.; Dathi, M. D.; Arigela, R. K.; Kundu, B. Tetrahedron 2012, 68, 8207-8215. doi:10.1016/j.tet.2012.07.067

68. Kumar, K. S.; Bhaskar, B.; Ramulu, M. S.; Kumar, N. P.; Ashfaq, M. A.; Pal, M. Org. Biomol. Chem. 2017, 15, 82-87. doi:10.1039/c6ob02340a

69. Pati, K.; Michas, C.; Allenger, D.; Piskun, I.; Coutros, P. S.; dos Passos Gomes, G.; Alabugin, I. V. J. Org. Chem. 2015, 80, 11706-11717. doi:10.1021/acs.joc.5b01014

70. Gulevskaya, A. V.; Shvydkova, E. A.; Tonkoglazova, D. I. Eur. J. Org. Chem. 2018, 5030-5043. doi:10.1002/ejoc.201800613

71. Gulevskaya, A. V. Eur. J. Org. Chem. 2016, 4207-4214. doi:10.1002/ejoc.201600660

72. Gulevskaya, A. V.; Tonkoglazova, D. I.; Guchunov, A. S.; Misharev, A. D. Eur. J. Org. Chem. 2019, 4879-4890. doi:10.1002/ejoc.201900818

\section{License and Terms}

This is an Open Access article under the terms of the Creative Commons Attribution License (https://creativecommons.org/licenses/by/4.0). Please note that the reuse, redistribution and reproduction in particular requires that the author(s) and source are credited and that individual graphics may be subject to special legal provisions.

The license is subject to the Beilstein Journal of Organic Chemistry terms and conditions:

(https://www.beilstein-journals.org/bjoc/terms)

The definitive version of this article is the electronic one which can be found at: https://doi.org/10.3762/bjoc.17.2 